\title{
STUDI FENOMENOLOGI TA'ARUF SEBAGAI CARA MENENTUKAN PASANGAN HIDUP PADA PARTAI KEADILAN SEJAHTERA
}

\author{
Asaas Putra \\ Program Studi IImu Komunikasi Fakultas Komunikasi dan Bisnis Universitas Telkom \\ Email: asaasputra@telkomuniversity.ac.id
}

\section{ABSTRAK}

Partai Keadilan Sejahtera merupakan partai yang sangat memperhatikan sistem kaderisasi pada organisasinya. Sistem kaderisasi ini membentuk sebuah sistem yang harus ditaati oleh para kadernya. Dalam sistem tersebut, termasuk juga aturan tentang hubungan antar pribadi setiap kader. Pada dasarnya, hubungan antar pribadi atau antar kader yang terdapat pada Partai Keadilan Sejahtera ini dimulai ketika kaderisasi. Kaderisasi ini dinamakan dengan model usrah (kumpulan orang-orang yang terikat oleh kepentingan yang sama, yakni: bekerja, berdakwah, men-tarbiyah [mendidik] dan mempersiapkan kekuatan untuk Islam). Kemudian setelah berkumpul, antar kader semakin dikuatkan melalui rukun-rukun. Rukun tersebut adalah saling mengenal (ta'aruf), saling memahami (tafahum) dan saling menanggung beban (takaful). Penelitian ini menggunakan metode kualitatif dengan pendekatan fenomenologi. Penelitian ini menggunakan tiga pasangan kader PKS, yang melakukan pernikahan dengan cara ta'aruf sebagai informan penelitian. Hasil penelitian ini menunjukkan bahwa terdapat perbedaan antara hubungan antar pribadi konvensional dengan hubungan antar pribadi yang diterapkan oleh PKS.

Kata Kunci : Ta'aruf, Komunikasi Interpersonal, PKS 


\section{Latar Belakang}

Secara lahiriah, manusia normal memiliki kecenderungan untuk tertarik dengan lawan jenisnya. Kecenderungan ini berakhir pada kebutuhan biologis, kebutuhan untuk berkembang biak serta mempertahankan jenisnya (species) sebagaimana makhluk hidup lainnya. Muhammad Fauzil Adhim, seorang dosen Psikologi Universitas Islam Indonesia Yogyakarta, dalam bukunya yang berjudul Indahnya Pernikahan Dini mengutip salah satu teori hierarki kebutuhan manusia (the hierarchy of needs) yang digagas oleh Abraham Maslow. Sederhananya, teori ini mengatakan untuk mencapai kebutuhan puncak, manusia terlebih dahulu memenuhi kebutuhan-kebutuhan yang ada di bawahnya. Sekalipun dimungkinkan terjadinya lompatan dalam memenuhi kebutuhan sehingga seseorang memenuhi kebutuhan yang ada di tangga lebih atas sebelum memenuhi kebutuhan yang ada pada tingkat di bawahnya, tetapi tidak terpenuhinya berbagai kebutuhan dasar cenderung menyulitkan seseorang memenuhi kebutuhan puncak.

Manusia merupakan makhluk sosial yang memiliki kecenderungan untuk berkelompok (gemaninschat) dan saling mengikat. Setiap komunitas manusia mempunyai norma tersendiri dalam mengatur hubungan antar pribadi. Norma tersebut bisa berangkat dari norma budaya ataupun norma agama. Partai Keadilan Sejahtera (PKS) merupakan salah satu bentuk komunitas yang mengatur hubungan antar pribadi anggotanya yang berangkat dari norma agama. Pentingnya memelihara hubungan antar pribadi dalam kader (Partai Keadilan Sejahtera menyebut anggotanya sebagai kader) merupakan bagian dari nizham (pandangan yang berisikan tujuan, cita-cita serta program hidup). Adapun bentuk hubungan tersebut adalah ta'aruf (saling mengenal), tafahum (saling memahami), dan takaful (saling menanggung beban). Ajaran-ajaran mengenai tatacara bergaul sesama muslim yang dianut oleh PKS itu sendiri bersumber dari Al- Qur'an dan Al-Hadist. (Damanik: 2002). Termasuk di dalamnya bagaimana memperlakukan sebuah hubungan antar pribadi yang berlawanan jenis.

Pentingnya sebuah hubungan antar pribadi dalam kader adalah untuk menjaga keutuhan (kohesivitas) komunitas atau kelompoknya. Untuk membina hubungan antar 
pribadi ini, para kader PKS membentuk suatu forum diskusi yang selalu rutin diadakan setiap minggu. Mengenai waktu disesuaikan dengan jadwal kegiatan setiap anggota forum. Forum ini biasanya berjumlah antara lima sampai sepuluh orang yang dipimpin oleh seorang pembina. Pembina ini biasanya disebut dengan murobbi sedangkan para anggota forum disebut dengan muttarobbi. Adapun forum tersebut dikenal dengan nama liqo. Liqo biasanya diadakan di mesjid-mesjid, rumah para anggota liqo atau di halaman kampus.

Dalam forum ini biasanya membahas mengenai masalah sehari-hari, bedah buku, tukar pendapat bahkan diskusi kuliah yang kemudian dikorelasikan dengan pandangan agama Islam. Biasanya dibuka dengan pembacaan ayat suci Al-Qur'an dan nasehat keagamaan dari sang murobbi. Dengan adanya kohesivitas kelompok atau rasa "ke-kita-an" ini, individu kelompok cenderung mencari pasangan hidup di internal kelompok tersebut atau sesama kader PKS, hal ini merupakan salah satu cara untuk mempertahankan keutuhan kelompok.

Hal terpenting mengapa peneliti begitu tertarik terhadap penelitian ini ialah mengenai hubungan antar pribadi terhadap lawan jenis dalam menuju jenjang pernikahan pada kader PKS, yang memiliki prosedur, dan menurut mereka seperti yang di-syari'at-kan (diatur) Islam. Suatu hal yang fenomenal adalah hubungan antar pribadi ini menggunakan istilah ta'aruf. Kata Ta'aruf sendiri secara harfiah berarti saling mengenal. Meski "mengenal" tersebut mempunyai makna yang luas, namun pada kenyataannya, sering terjadi penyempitan makna, contohnya seorang kader ikhwan (kata ganti kader pria) mengatakan bahwa ia sedang ta'aruf dengan seorang akhwat (kata ganti kader wanita) bernama Y. Kalimat ikhwan itu bisa diartikan bahwa dia sedang melakukan pendekatan dengan akhwat dalam rangka menuju ke jenjang pernikahan sesuai dengan syari'at Islam. Tren ini, seolah telah menjadi fenomena tersendiri di kalangan generasi muda kaum terpelajar dan profesional-profesional muda muslim di kota-kota besar yang menjadi basis gerakan kader PKS.

Pada organisasi PKS, rata-rata menganjurkan kepada kadernya untuk menyegerakan menikah bila segala syarat telah terpenuhi. Walaupun anjuran seperti ini 
tidak tertuang secara tertulis dalam bentuk aturan, akan tetapi di dalam setiap forum liqo, anjuran ini selalu ditekankan oleh para murobbi kepada muttarobbi-nya. Anjuran tersebut tidak mengandung sanksi bila sang muttarobbi tidak melaksanakannya karena mempertimbangkan juga kondisi dan keadaan sang muttarobbi. Adapun salah satu dalil mengenai menyegerakan menikah ialah: "Hai para pemuda! Barangsiapa di antara kamu sudah mampu menikah, maka menikahlah. Karena menikah itu dapat menundukkan pandangan dan menjaga kemaluan" ( HR. Bukhari) .

Selain dalil tersebut, alasan mengapa setiap murrobbi menganjurkan menyegerakan menikah tak lain adalah karena PKS merupakan partai yang rutin melakukan kaderisasi. Hampir sebagian besar kader partai ini berasal dari kaum muda, mahasiswa dan para profesional muda yang rata-rata belum menikah sehingga pembahasan mengenai pernikahan adalah suatu hal yang banyak menarik perhatian kader pertai ini.

Jenis komunikasi antar pribadi yang terjadi pada ta'aruf ini biasanya bentuk komunikasi triadik (triadic communication), karena murobbi ataupun ustadz berperan aktif dalam membina hubungan antar pribadi muttarobbi-nya. Bila seorang muttarobbi telah menyatakan kesanggupannya untuk menikah, maka murobbi akan mencarikan pasangan yang cocok baginya. Proses pencarian ini melalui ustadz atau sesepuh yang dituakan atau orang yang dianggap mengerti ataupun jaringan sesama murobbi. Pada masyarakat awam dikenal dengan istilah mak comblang. Sekilas proses ini tampak seperti layaknya perjodohan di beberapa kebudayaan tradisional yang ada di Indonesia, namun proses ini sebenarnya mengandung nilai- niali serta esensi Islami.

Di beberapa jaringan liqo, ataupun di beberapa ustadz yang bertindak sebagai penghubung ta'aruf, ada yang mewajibkan murobbi-nya untuk menyiapkan proposal. Layaknya sebuah proposal proyek, sang muttarobbi yang berniat berumah tangga akan menjelaskan visi dan misi hidupnya, rencana ke depan, pendapatan per bulan, jumlah kekayaan yang dimiliki, kesanggupan membiayai sang calon istri (bagi ikhwan) dan kesanggupan melayani suami (bagi akhwat), riwayat kesehatan (ada tidaknya penyakit 
turunan) dan lain sebagainya yang berhubungan dengan kepribadian si pemilik proposal termasuk foto diri di dalam proposalnya.

Adapun poin-poin mengapa ta'aruf diberlakukan pada kader PKS ini ialah :

1. Menghargai martabat wanita.

2. Menghindari fitnah

3. Mengingatkan pentingnya hidup berjamaah yang saling menasehati sesama.

4. Menjaga kesucian jiwa dan hati.

5. Menjaga keutuhan komunitas (kohesivitas kelompok)

6. Mempermudah dakwah

Di dalam ilmu komunikasi, kita mengenal DeVito dengan pemikirannya mengenai komunikasi antarpribadi dalam bukunya yang berjudul Human Communication. Di dalam buku tersebut, DeVito mengutip model lima tahap hubungan antar pribadi Knapp. Knapp menguraikan tahap-tahap penting dalam pengembangan hubungan. Kelima tahap ini ialah kontak, keterlibatan, keakraban, perusakan dan pemutusan (DeVito, 1996:233).

Pada model lima tahap Knapp yang dikutip DeVito ini, terdapat beberapa kesamaan pengertian dengan model hubungan yang dikembangkan oleh PKS. Model tersebut seperti telah diterangkan di atas adalah ta'aruf (saling mengenal), tafahum (saling memahami), dan takaful (saling menanggung beban). Namun pada tahapan yang keempat dan yang kelima pada model DeVito tidak dikenal pada model hubungan antarpribadi ala PKS ini. Hal tersebut disebabkan oleh adanya larangan pemutusan hubungan silaturahmi dalam konsep ajaran Islam.

\section{Perumusan masalah}

Dalam penelitian ini dirumuskan pertanyaan yaitu bagaimana ta'aruf sebagai sebuah hubungan antarpribadi dijadikan pencarian pasangan hidup?

\section{Metode Penelitian}

Metode penelitian ini menggunakan metode kualitatif dengan pendekatan fenomenologis. Sepasang informan pelaku ta'aruf digunakan sebagai informan utama dan lima orang sebagai informan pendukung. Penelitian ini dilakukan di Bandung dan 
Jakarta. Teknik pengumpulan data yang digunakan adalah observasi partisan, wawancara mendalam dan studi literatur. Data yang diperoleh kemudian dianalisis guna mendapatkan makna terhadap data tersebut.

\section{Hasil dan Pembahasan}

Dalam penelitian ini, sebagai rujukan, peneliti menggunakan pokok pikiran Knapp yang terdapat pada Human Communication yang ditulis oleh DeVito, dalam membahas forum liqo sebagai sebuah komunikasi antarpribadi dan kohesivitas para anggota forum tersebut. Ta'aruf, menurut sumber resmi DPD Partai Keadilan Sejahtera Bandung yaitu Bapak Icin, tidak terlepas dari model pengembangan kaderisasi berbentuk Daurah, yang dikembangkan oleh Dewan Pimpinan Pusat Departemen Kaderisasi PKS. Berikut adalah pernyataan beliau kepada peneliti :

"Partai Keadilan Sejahtera memandang bahwa pengembangan sumber daya manusia tidak bisa hanya satu sisi, pengembangan sumber daya manusia sangat dipengaruhi oleh berbagai potensi. Potensi tersebut tak terlepas dari potensi jasad (jasmani), fikroh (fikiran) rukhyah (hati). Dari ketiga dasar potensi itu, Partai Keadilan Sejahtera mengembangkan berbagai macam daurah ataupun training. Daurah tersebut berbentuk daurah tarbawiah (tarbiyah pendidikan untuk membina akal), mabit (menginap di tempat tertentu), tadabur (mensyukuri) alam secara berkelompok dan lain sebagainya. Dan setiap program kaderisasi itu akan dievaluasi (mutabaah/ muhasabah), yang dilakukan oleh pembimbing setiap kelompok. Di dalam kegiatan daurah itulah setiap kader diharuskan untuk saling mengenal secara personal tiap anggota kelompoknya. Ini dimaksudkan agar setiap anggota dari kelompok tersebut dapat saling bekerja sama.

Di dalam daurah, dikenal tiga tingkatan hubungan antar pribadi yang harus dikembangkan oleh setiap kader. Hal ini merunut pernyataan sahabat Nabi, Abu Bakar, yang mengatakan 'Kamu belum menjadi seorang sahabat ketika kamu tidak pernah tahu tidurnya, makannya, dan jalannya sahabat kamu'. Ketiga tingkatan tersebut adalah ta'aruf, tafahum, dan takaful. Ketiga tingkatan ini menjadikan parameter kedekatan hubungan antar pribadi antara kader dalam suatu kelompok liqo dengan yang lainnya."

Ta'aruf adalah mengenalkan diri sesama kader. Biasanya di sini terjadi pengungkapan biodata seperti nama, alamat, nama orang tua dan lain-lain secara lisan. Semakin kecil sebuah forum, akan semakin detail juga pengungkapannya. Pada saat 
inilah seseorang mengambil keputusan apakah hubungan terus berlanjut atau akan berhenti pada tahapan ini. Namun karena awal dari perkenalan tersebut adalah karena Allah dan demi dakwah, maka penampilan fisik hampir tidak menjadi pertimbangan pada kelompok ini.

Setelah ta'aruf, apabila forum tersebut secara kontinyu melakukan pertemuan semisal liqo, maka pada pertemuan berikutnya akan terjadi tafahum. Tafahum secara harfiah berarti saling memahami. Tahapan ini menurut Knapp adalah tahap keterlibatan. Artinya, pada tahapan ini setiap pribadi telah saling membuka diri untuk lebih mengenal yang lainnya. Takaful secara harfiah berarti saling menanggung beban. Pada tahapan ini, para kader sudah merasa seperti sebuah keluarga. Tahapan ini menurut Knapp adalah tahap keakraban. Knapp menyebutnya sebagai hubungan primer (primary relationship) yang membentuk komitmen untuk menanggung beban secara bersama.

Pada dasarnya mengenai pendapat yang mengatakan bahwa tidak semua kader PKS adalah harakah tarbiyah, Bapak Icin mengatakan:

"Memang betul, kita berpartai dan berpolitik merupakan kewajiban seorang muslim terhadap agamanya, karena merupakan sebagian dari ajaran agama. Ada yang menganggapnya sama saja dengan tidak usah masuk partai politik. Sebenanya tidak sama, karena (dalam partai) kita terjaga. Ada beberapa anggota yang belum ter-tarbiyah dan itu merupakan tantangan bagi Partai Keadilan Sejahtera. Bahkan, di zaman Rasulullah, orang-orang munafik seperti Abdullah bin Ubay bin Shaum sholatnya tepat di belakang Rasullullah dengan takbir yang paling kencang. Karena itu setiap anggota Partai Keadilan Sejahtera harus terlibat tarbiyah, dengan sistem daurah sistem murobbi".

Dari pengamatan peneliti, hal yang sama juga terjadi pada setiap halaqoh atau kelompok liqo, yang setiap anggotanya sudah mencapai tingkatan hubungan antar pribadi tertinggi (mengingat intensitas komunikasi dan pertemuan yang rutin). Layaknya sebuah saudara, mereka akan saling menanggung beban antara satu dengan yang lain, hingga ke urusan finansial dan hal-hal pribadi yang bersifat positif dan sesuai dengan ajaran agama Islam -atau istilah Partai Keadilan Sejahtera selama masih istiqomah (suci qalbu di jalan Allah) dan dalam koridor syari'at (ajaran/ aturan) Islam-. 
Model kaderisasi seperti ini kemudian diturunkan menjadi sebuah model pencarian pasangan hidup, artinya tahapan awalnya adalah ta'aruf. Ta'aruf dalam arti pencarian pasangan hidup mengandung sedikit komunikasi antar pribadi. Artinya, komunikasi antar pribadi secara konvensional (terjadinya tatap muka atau kontak langsung) dilakukan sesedikit mungkin. Pertemuan yang tidak melibatkan pihak ketiga adalah hal yang sangat jarang terjadi dan bahkan dilarang. Agama Islam sangat melarang pertemuan dua individu berbeda gender bertemu, berbicara dan tidak pada tempat yang pantas tanpa disertai pihak ketiga. Larangan ini selain karena takut menimbulkan fitnah, juga menghindari perbuatan yang tidak terpuji.

Adapun mengenai proses ta'aruf, Bapak Icin mengatakan:

"Proses terjadinya ta'aruf biasanya dimulai dari pihak ikhwan/ pria ketika menyatakan siap untuk berumah tangga dengan menyerahkan biodata kepada murobbi. Karena proses daurah yang telah berlangsung lama antara kader dan murobbi, maka murobbi mengetahui betul watak, tingkat keimanan, sifat, serta keinginan muttarobbi-nya. Kedekatan antara sang murobbi dengan muttarobbi tak terlepas dari daurah dengan sistem usrah itu sendiri, yang mendekatkan antara keduanya. Tingkat intensitas hubungan antar pribadi layaknya keluarga telah menghilangkan halangan-halangan dalam pengungkapan diri".

Dari pengalaman peneliti yang mencoba bergabung dalam sebuah forum liqo, salah satu penyebab hilangnya halangan-halangan tersebut adalah sesi khodoya wal khulul (masalah dan pemecahan/ curahan hati) dalam setiap liqo. Pada sesi ini, salah satu anggota yang sedang menghadapi masalah dalam hal apapun termasuk kehidupan pribadi dapat membahasnya dengan sesama anggota kelompok atau sang murobbi. Dengan demikian, wajar bila murobbi diasumsikan mengerti dengan watak, tingkat keimanan, sifat serta keinginan muttarobbi-nya. Setelah murobbi menerima biodata, murobbi tersebut kemudian mencarikan biodata akhwat yang kira-kira cocok dengan muttarobbinya.

Menurut Bapak Icin, cara ta'aruf ini pernah dicontohkan Nabi. Dalam gaya bahasanya yang khas, Bapak Icin mengatakan:

"Rasulullah bertanya kepada salah seorang sahabatnya kenapa kamu belum menikah? Kata sahabatnya, baik Rasulullah, saya akan 
menikah. Rasulullah bertanya, sudah punya pasangan? Sahabat itu kemudian menjawab, saya terserah Rasullullah saja. Baik, kata Rasulullah, saya ada calon untuk kamu. Sahabat tersebut menjawab saja, baik, ya Rasullullah saya siap nikah. Rasulullah bertanya lagi, kenapa kamu tidak melihat dulu? Dari cerita tersebut bisa kita ambil hikmah bahwa Rasulullah pun menyarankan untuk orang yang mau menikah untuk melihat dahulu calon pasangannya untuk saling mengklarifikasi mengenai hal-hal yang sekiranya mengganjal."

Mengenai ta'aruf sebagai pencarian pasangan hidup yang dianggap oleh sebagian orang dengan istilah "beli kucing dalam karung" (peneliti pernah mewawancara seseorang yang dapat mewakili masyarakat awam, muslim, yang menyatakan pendapatnya tentang proses ta'aruf), Bapak Icin mengatakan:

"Di tarbiyah itu, kita ada istilahnya jalur, dan ada juga yang non jalur. Jalur artinya melalui murobbi/yah. Mereka yang ta'aruf justru tidak seperti membeli kucing dalam karung karena saling menukar data lewat murobbi/yah yang sangat lengkap bahkan sampai penyakit turunan pun bisa kita ketahui. Justru dengan pacaran, kita tidak bisa tahu hal-hal seperti itu. Artinya, pacaran justru yang seperti membeli kucing dalam karung."

Selain itu, dalam mencarikan pasangan hidup untuk muttarobbi-nya, seorang murobbi harus melihat beberapa faktor. Hal ini diungkapkan oleh Bapak Icin kepada peneliti:

"Faktor terpenting yang menjadi pertimbangan seorang murobbi dalam mencarikan pasangan mutarobbi-nya ialah kesamaan kufu (derajat) atau biasa disebut dengan kese-kufu-an. Kese-kufu-an itu baik dalam tingkatan tarbawiyah (pendidikan), ekonomi, tingkat pendidikan, budaya dan lain sebagainya. Hal seperti ini pernah dicontohkan Rasulullah SAW ketika beliau mempersaudarakan kaum muhajirin (pendatang atau pengungsi) dengan kaum anshor (penduduk asli Kota Madinah). Rasulullah pada saat itu mempersaudarakan kedua kaum ini berdasarkan kese-kufu-an. Hal tersebut dilakukan Rasulullah agar tidak terjadi jurang pemisah yang terlalu lebar antara kaum yang dipersaudarakannya. Secara prosedural tata cara seperti di atas telah diatur oleh Divisi Pemberdayaan Wanita dan telah berbentuk dalam suatu prosedur. Namun nantinya akan dibentuk lagi suatu divisi pada 
DPD Partai Keadilan Sejahtera Bandung yang bertugas mengatur pernikahan kader-kadernya. Divisi itu bernama Lajnah Munakahat (Divisi Pernikahan)“.

Adapun poin-poin mengapa ta'aruf diberlakukan pada kader Partai Keadilan Sejahtera ini menurut Kang Herlan, seorang murobbi, yang dibenarkan oleh Bapak Icin adalah:

"Menghargai martabat wanita, menghindari fitnah, mengingatkan pentingnya hidup berjamaah yang saling menasehati sesama, menjaga kesucian jiwa dan hati, menjaga keutuhan komunitas (kohesivitas kelompok), dan terakhir, mempermudah dakwah"

Forum liqo tidak hanya merupakan sebuah focus group discussion. Lebih dari itu, liqo sudah melibatkan kesatuan psikologis dalam berinteraksi. Karena itu, forum liqo lebih tepat disebut sebagai situasi kelompok (group situation). Forum Liqo sama seperti yang didefinisikan oleh Robert F. Bales dalam bukunya Interactio Process Analysis tentang sebuah kelompok kecil:

"Sejumlah orang yang terlibat dalam interaksi satu sama lain dalam suatu pertemuan yang bersifat tatap muka (face-to-face meeting), dimana setiap anggota mendapat kesan atau penglihatan antara satu dengan yang lainnya cukup kentara, sehingga dia, baik pada saat timbul pertanyaan maupun sesudahnya, dapat memberikan tanggapan kepada masing-masing sebagai perorangan."

Jika dilihat dari karakteristik kelompok yang dibagi oleh DeVito, maka forum Liqo memiliki semua ciri yang dibedakan oleh DeVito. Keempat karakterisitik kelompok tersebut adalah sebagai berikut: Kelompok pemecahan masalah, kelompok pengembangan ide, kelompok pengembangan pribadi, kelompok belajar (DeVito; 1989) terdapat semuanya pada forum liqo. Sebagai kelompok pemecahan masalah, forum liqo memiliki sesi khodoya wal khulul (masalah dan pemecahan/ curahan hati). Sebagai kelompok pengembangan ide, dalam forum liqo terdapat sesi dimana setiap anggota wajib memberikan informasi mengenai hal-hal terbaru atau pengetahuan yang ia miliki (bisa dari kapasitas atau latar belakang pendidikannya) kepada anggota yang lain. Sebagai pengembangan pribadi, forum liqo rutin mengadakan mabit (menginap) di 
masjid, pesantren, rumah salah satu anggota, atauupun tadabur alam (menikmati alam/ hiking, kegiatan alam). Sebagai kelompok belajar, dalam forum liqo terdapat sesi tausiah (nasihat, ilmu pengetahuan umum yang dikorelasikan dengan agama) yang disampaikan oleh murobbi di setiap pertemuan. Sehingga forum liqo sesuai dengan empat karakteristik kelompok yang disebutkan oleh DeVito.

Pada tahapan hubungan antar pribadi yang dikembangkan oleh Partai Keadilan Sejahtera di atas, dapat kita lihat bahwa terdapat persamaan pengertian dengan tahapan hubungan antar pribadi yang diungkapkan oleh Knapp. Knapp menyebutkan terdapat lima tahapan hubungan antar pribadi. Tahapan tersebut adalah kontak, keterlibatan, keakraban, perusakan, dan pemutusan. Dua tahapan terakhir tidak terdapat dalam metode usrah, karena hal ini sangat bertentangan dengan syariat Islam yang melarang keras pemutusan hubungan silahturahmi sesama muslimin.

Informan dalam penelitian ini bernama Ade (nama samaran). Ade yang berlatar pendidikan Sarjana Matematika dari salah satu Perguruan Tinggi Negeri Kota Bandung ini, merupakan tipikal ideal profesional muda yang cukup berada. la pegawai negeri di sebuah Perguruan Tinggi Negeri dan mengajar di beberapa Perguruan Tinggi Swasta.

Ade mengatakan bahwa saat ia memutuskan untuk memilih metode ta'aruf $^{\prime}$ sebagai cara menentukan pasangan hidupnya, tak lain itu dilakukan karena bentuk ketaatan seorang kader terhadap lembaganya, dan menjaga kohesivitas kelompok dakwahnya yang telah lama ia tekuni. Ade tak ingin kelak suatu saat ketika menikah, aktifitas dakwahnya terganggu akibat kurangnya pemahaman agama pada istrinya.

Sebelumnya, Ade tidak begitu paham akan ta'aruf. Ketika ditanya sejak kapan dia mengetahui metode ta'aruf, Ade mengatakan:

“Awal-awal mulai mengaji, saya tidak tahu. Tahunya ketika kakak saya yang Partai Keadilan Sejahtera menikah. Tapi lama kelamaan terlibat dalam partai, saya jadi tahu juga."

Ade yang berasal dari keluarga menengah dan beberapa saudaranya merupakan pendiri dan pengasuh pondok pesantren di sekitar kota Bandung ini berpendapat bahwa dalam menentukan pasangan hidup, perempuan yang menjadi istrinya adalah akhwat yang telah ter-tarbiyah. Artinya, perempuan tersebut harus berasal dari komunitasnya 
yaitu harakah tarbiyah atau dengan kata lain merupakan anggota Partai Keadilan Sejahtera yang telah terbina dalam dakwah. Dalam menentukan pasangan hidupnya, Ade mengatakan :

"Dalam hadits, Rasulullah bersabda, 'Dinikahi seorang wanita karena empat perkara: karena hartanya, keturunannya, kecantikannya dan agamanya. Maka pilihlah karena agamanya, maka akan selamatlah engkau..."

Satu-satunya cara dalam mencari pasangan hidup yang dirasa cocok menurut hadits tersebut ialah dengan metode ta'aruf. Dengan metode ta'aruf, pilihan pasangan hidup relatif lebih terbuka dan terjamin. Mengenai keterbukaan ini, Ade mengatakan:

"Terbuka karena di dalam biodata calon istri telah terdapat hal-hal yang spesifik. Di dalam biodata dicantumkan nama lengkap, nama panggilan, pas foto, tinggi badan, berat badan, hobi, kebiasaan jelek, kebiasaan buruk, tempat tanggal lahir, pekerjaan, riwayat pendidikan, buku yang dibaca, suku bangsa, lama tarbiyah, organisasi yang pernah diikuti, kegiataan dakwah yang pernah diikuti, prestasi, penyakit yang pernah diderita, nama orang tua, pekerjaan orang tua, jumlah saudara kandung, pekerjaan orang tua, alamat orang tua, nama saudara kandung, status menikah saudara kandung, pendidikan saudara kandung terakhir nama dan nomor telepon murobbi sebagai orang yang dihubungi untuk memulai kontak."

Sedangkan tentang keterjaminan, Ade berpendapat:

"Seorang akhwat yang ter-tarbiyah tentunya sudah tidak diragukan lagi pengetahuan agamanya, dan tentunya sudah terjaga akhlak maupun tindakanya".

Ade berpendapat ada dua jalur yang dapat ditempuh dalam ta'aruf ini. Ade menyebutnya dengan "jalur negeri" dan "jalur swasta". "Jalur negeri" artinya melalui jalur murobbi. Artinya, seorang muttarobbi akan menyerahkan sepenuhnya urusan pencarian calon pasangannya kepada murobbi-nya, sesuai dengan kriteria yang telah dia tetapkan pada biodatanya. Murobbi bertindak penuh sebagai wasilah (perantara) dalam mencari pasangan. Selanjutnya, murobbi akan melakukan kontak dengan jaringannya untuk mencari pasangan yang kira-kira cocok dengan yang dikehendaki mutarobbi. "Jalur swasta" adalah cara pencarian sendiri. Artinya, mutarobbi akan mencari sendiri 
calon istri yang ia inginkan (dalam lingkup Partai Keadilan Sejahtera) yang kemudian dikonsultasikan kepada murobbi-nya. Selanjutnya, murobbi akan menghubungi murobbiyah calon istri yang telah ditentukan oleh muttarobbi tadi dan murobbi tetap menjadi wasilah. Perbedaaannya hanya pada pencarian, selanjutnya tidak ada perbedaan.

Jodoh Ade sendiri akhirnya merupakan akhwat yang juga sesama aktivis dalam partai. Akhwat tersebut cukup sering terlibat kontak komunikasi dengan Ade dalam kegiatan dakwah sehingga keduanya sudah saling mengetahui integritas masing-masing. Setelah membicarakan dengan Annisa dan mendapat tanggapan positif, Ade segera menghubungi murobbi-nya. Selanjutnya, murobbi dari Ade mengontak murobbiyah dari Annisa tersebut untuk menyepakati pertukaran biodata.

Setelah membaca biodata Annisa, Ade merasa lebih yakin tentang pilihannya. Biodata Ade sendiri dilengkapi dengan cerita tentang keadaan keluarga besar, dan kegiatan sehari-hari keluarga, kegiatan dakwah, pekerjaan sehari-hari serta keinginan yang akan diwujudkan kelak dengan calon istrinya. Selanjutnya, disepakati untuk melakukan pertemuan ta'aruf di rumah murobbiyah dari Annisa. Antara ta'aruf hingga terjadinya khitbah (pinangan/lamaran), keduanya hanya memerlukan waktu seminggu. Sedangkan dari khitbah menuju ke akad nikah dan walimah diperlukan waktu sekitar tiga bulan. Selama tiga bulan itulah waktu Ade untuk membangun sebuah hubungan antar pribadi tahap awal setelah terjadi kontak pada pertemuan pertama. Setelah itu, komunikasi hanya pertemuan yang disertai pihak ketiga ataupun keluarga, kegiatan dakwah, yahoo messenger atau chatting, SMS melalui telepon genggam dan komunikasi langsung melalui telepon.

Menurut Ade tentang khitbah:

"Setelah ta'aruf, prosesi berlanjut ke khitbah. Yang menjadi fokus adalah menghadapi hari-H pernikahan, bukan tentang personal calonnya."

Ketika ditanyakan batasan komunikasi yang boleh dibicarakan, Ade mengatakan :

"Sempat bertanya ke murobbi, kira-kira batasan komunikasinya seperti apa, boleh tidak menggunakan media seperti yahoo messenger? 
Kata murobbi boleh saja, selama tidak boleh melampaui batas. Contoh kasus, saya pernah ketika proses komunikasi itu mengajak makan malam. Ternyata dia marah karena mungkin hal seperti itu dianggap penyimpangan. Padahal maksud saya adalah mendekati adiknya, bukan makan malam berdua. "

Tentang masalah ini, Ade menganggap hanya terjadi kesalahan pengertian (miss communication) dan membuat dirinya semakin berpersepsi positif terhadap calon istrinya tersebut. Artinya, calon istrinya tersebut sangat menjaga hijab.

Tiga bulan setelah ta'aruf, Ade melaksanakan akad nikah dan walimah yang keseluruhan prosesinya hanya memakan waktu kurang lebih tiga bulan. Pada saat itu, usia Ade adalah 26 tahun dan usia Annisa adalah 24 tahun. Ketika peneliti menanyakan apakah cara seperti ini akan mereka rekomendasikan kepada teman-teman mereka, Ade menjawab ya, termasuk kepada peneliti sendiri. Adapun wawancara dengan Annisa peneliti lakukan secara tidak langsung yaitu melalui media pertanyaan tertulis dan melalui Ade.

\section{Kesimpulan}

Dari penelitian di atas, peneliti menyimpulkan bahwa ta'aruf adalah sebuah hubungan antarpribadi yang kemudian dikembangkan menjadi model pencarian pasangan hidup yang menyertakan wasilah (perantara), dimana di dalamnya terdapat komunikasi antar pribadi untuk membangun sebuah hubungan antarpribadi, dengan batasan sesuai dengan aturan agama Islam. Selain itu juga, ta'aruf berfungsi untuk meminimalkan perbedaan atau dalam rangka mencari kesamaan (kese-kufu-an). 


\section{Daftar Pustaka}

Abdullah, Fathi. 2004. Adab dan Tuntunan Meminang. Jakarta: Pustaka Qalami.

Amirudin, Aam. 2009. Transformasi Indentitas Aktivis Gerakan Tarbiah Setelah Menjadi Aktivis Gerakan Politik. Bandung: Universitas Padjadjaran.

Bahresy, Hussein. 1996. Himpunan Hadist Pilihan Hadist Shahih Bukhari. Surabaya: Al Ikhlas.

Damanik, Alis S. 2002. Fenomena Partai Keadilan. Jakarta; Teraju

Devito, Joseph. 1997. Komunikasi Antar Manusia. Jakarta: Professional Book.

Effendy, Onong. 2003. Ilmu, Teori dan Filsafat Komunikasi. Bandung: Citra Aditya Bakti.

Magdalena, Shanty. 2007. Komunikasi Interpersonal dalam Menyelesaikan Konflik Antara Suami Istri yang Baru Menikah, Surabaya: Petra Christian University.

Nasution S. 1988. Metode Penelitian Naturalistik Kualitatif. Bandung: Tarsito. 